\title{
Dynamics of Clan Based Conflicts in Wajir County, Kenya
}

\author{
David Karienye, Prof Osman Warfa \\ Lecturer School of Education Arts and Social Science Garissa University, Kenya \\ dkarienye@gmail.com
}

\begin{abstract}
Clannism is one of the key drivers of violent attacks in Northern Kenya. The causes of the persistent clan-based conflicts in Northern Kenya are not well known and ascertained. The rising incidents of violent attacks which clan-based conflict can be partially blamed, which this study attempted to explore. This underpins the need to conduct research in order to explore the drivers of clan-based conflict in Wajir county. The specific objective of the study was to assess the drivers of inter-clan and intra-clan-based conflicts in Wajir county, Kenya. The study adopted an exploratory research design. The study involved qualitative approach of data collection. The target population comprised of clan elders (Degodia, Ogaden and Ajuran), security agents, religious leaders and civil society organizations. A total of 31 respondents were interviewed who were selected using purposive and snowball approach. Interview guides were administered to the various respondents. The information obtained in the study was thematically analyzed according to the research questions. The study found that some of the key drivers of clan conflict in Wajir County include political influence, constituency boundaries, unequal sharing of county resources and competition over water and pasture. Findings from this study will be published to aid in disseminating information on the best ways to mitigate the clan-based conflict.
\end{abstract}

\section{Keywords} clan; conflicts; Wajir; Kenya; violent extremist

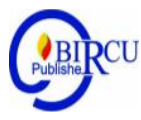

\section{Introduction}

Ngala (2016), noted the relationship between violent extremism and clan-based conflict in Northern Kenya is very complex. Factors driving clan-based conflicts produce a fertile ground for violent extremism. The rapid formation of new state institutions, which are mostly independent state commissions, is a worldwide phenomenon, and is caused by various social and economic changes (Demas et al, 2020). Devolved government system in Kenya which was designed to address decades of political marginalisation and underdevelopment, has been undermined by dominant clans monopolising power and growing corruption hence is a major driver of clan conflict (Policy Briefing Africa, 2012).

Violent extremism does not develop in isolation but feeds upon and exploits a wide variety of societal conditions presented in a given community, country, or broader geographical area, for this case clan conflict is assumed to be one of the conditions that driver violent extremism. According to Demas et al, (2020), institutional design of the state with 
separation of powers and checks and balances bore intersection of authority, functional relationships or relationships of coordination among the institutions. Thus, in order to understand violent extremism, it is important to understand the role of clan conflict within the society.

The three counties in Northern Kenya namely Garissa, Wajir and Mandera have been facing great security challenges since October $16^{\text {th }} 2011$ when Kenyan military troops crossed border to Somali (Joint report by Garissa County Steering Group and Kenya Food Security Steering Group (KFSSG) 2016). In principle, there are two possibilities of defence against such terrorist attack for the Kenyan case: to fortify the borders by mean of strengthening it having more security personnel along the porous boundaries or to invade offensively the spaces beyond the borders with intention of keeping the attackers away. The Kenyan government opted to allow Kenya Defense Forces to cross to Somalia with the intention of securing Kenya operation called Linda Nchi (Protect the Country), to the reality of the alShabaab menace in the Country (Miyandazi, 2012). The Kenyan intervention in the Somalia conflict is fraught with its own challenges for Kenya, Somalia and the entire region.

The KFSSG report (2016) cited that the Northern Kenya counties have only $7 \%$ of the total population engaged in either formal employment or business and about $3 \%$ of the populations are agro-pastoralists while $90 \%$ are pastoralists. According to this report the major threats to their peace is security and stability in the counties and limited resources that include unreliable rains (water shortage), grazing areas, floods and prevalence of livestock diseases. Other major challenges faced are water and sanitation, and political based conflicts related to clan supremacy where one clan want to dominate in the political circles while discrimination of the minorities who cannot make any political decision. The minority clan has less number and thereby cannot win any electioneering process remaining in the hand of the supreme clan. The supremacy in clannism accelerates clan conflict with aim of retain the political influence.

There have been persistent clan-based conflicts in Northern Kenya and their causes are not well known and ascertained. There are unresolved clan conflicts coupled with many youths who are unemployed that may be availing themselves for the cause of the clan that need to be unearthed. Scholars have given little empirical factors driving clan-based conflict which yield a fertile ground for violent extremism one factor being proximity to Somali and Ethiopia border. This creates dilemma that external forces of violent extremists may have infiltrated and providing support to certain clans for defence and other opportunities. This underpins the need to conduct research in order to explore dynamics of clan-based conflicts in Wajir County, Kenya.

\section{Review of Literature}

Wajir County is inhabited by three major clans namely; Degodia, Ogaden and Ajuran. A conglomerate of elements from various other clans collectively referred to as 'the corner tribe' also live in Wajir (Omosa, 2005). Ajuran have settled in Wajir North, Ogaden in Wajir South while Degodia in Wajir West and East. The main sub-clans of Degodia are Masaare, Fai and Jibrael while the sub -clans for Ajuran are Gelbaris and Waqle. Fai the sub-clan of Degodia are the majority in the clan of Degodia. Ajuran claim to be Wajir's original inhabitants but the 
recently settled Degodia have dominated political positions (Menkhaus, 2008). Whereas the Ogaden is part of the Darood clan family and the Degodia part of the Hawiye matrilineal, the Ajuran is not classified into any of the clan families (Lewis, 1961). The Darood and

the

Hawiye are generally hostile to each other. The Degodia clan, is the majority in Wajir followed by the Ogaden and Ajuran respectively. Clan majority has been variously utilized to gain political and economic power through manipulative and exploitative means.

Wajir county has six constituencies namely Eldas, Wajir West, Wajir North, Tarbaj, Wajir East and Wajir south. The Degodia are largely settled in Wajir West, Eldas, Tarbaj and Wajir East while the Ajuran and the Ogaden are the majority in Wajir North and Wajir South respectively. In Wajir town all the clans have settled there including the 'Corner Tribe'. Each clan has authority over the politics and resources within its settlement (Omosa, 2005). In Wajir County, inter and intra clan conflict exist as stipulated in table 1 below.

Table 1. Clan based conflicts Incidents in Wajir County Kenya 2014-2018

\begin{tabular}{|c|c|c|c|}
\hline Date & Incident & Place & Details \\
\hline $\begin{array}{l}\text { June 20, } \\
2014\end{array}$ & $\begin{array}{l}\text { Intercommunity } \\
\text { rivalry }\end{array}$ & $\begin{array}{l}\text { Eldas, Wajir } \\
\text { North }\end{array}$ & $\begin{array}{l}\text { Five killed, lorry set on fire, looting } \\
\text { by suspected Unknown militia. }\end{array}$ \\
\hline $\begin{array}{l}\text { June } 21 \text {, } \\
2014\end{array}$ & Clan violence & $\begin{array}{l}\text { Wajir-Mandera } \\
\text { counties border }\end{array}$ & $\begin{array}{l}\text { Twenty killed, five injured, thirty- } \\
\text { five houses burned down }\end{array}$ \\
\hline $\begin{array}{l}\text { June /July } \\
2015\end{array}$ & $\begin{array}{l}\text { Clan Conflict } \\
\text { Degodia and Ajuran } \\
\text { Clan }\end{array}$ & $\begin{array}{l}\text { Eldas-Wajir } \\
\text { North sub } \\
\text { counties border }\end{array}$ & $\begin{array}{l}\text { Fifteen killed, nine injured and } \\
\text { others displaced }\end{array}$ \\
\hline $\begin{array}{l}\text { Novembe } \\
\text { r } 2016\end{array}$ & $\begin{array}{l}\text { Clan rivalry- Degodia } \\
\text { sub-clans of Matan } \\
\text { and Jibrail }\end{array}$ & $\begin{array}{l}\text { Baqala, Wajir } \\
\text { West }\end{array}$ & $\begin{array}{l}\text { Eight people killed and two others } \\
\text { injured with serious wounds }\end{array}$ \\
\hline Feb 2018 & Clan conflicts & $\begin{array}{l}\text { Eldas and Buna } \\
\text { Sub-Counties in } \\
\text { Wajir. }\end{array}$ & 11 killed \\
\hline
\end{tabular}

Authors assorted Literature (2018)

Incidents of clans' conflicts and attacks before 2014 in Wajir County were minimal compared to the adjacent counties of Mandera and Garissa. This can partially be attributed to the working of Wajir Peace and Development Committee (WPDC) which was established in 1994. The WPDC maintained the sustainable peace within the County and thus stimulated the reconciliation process hence reducing incidence of clan conflicts. According to Ngala (2016), the WPDC worked with formal government officials in conflict mitigation, resolving conflicts and accommodating rivals' interests among different clans and this worked to reduce levels of violence in Wajir. However, local capacities have been weakened by recent developments both political devolution and the emergence of Al-Shabaab as a security threat by those who resist those in power. Although Foucault's notion of power in Kate Chopin's believes that the subject is constituted by power, he does not reject the idea of resistance to the power among the oppressed (Narges, 2020). Incidence of attacks after 2014 was compounded by Al-Shabaab infiltration, Kenya defence force entering Somali, radicalisation and recruitment especially in 
the borderland region where the inhabitants' national identity is historically contested and suspected (Crisis Group Africa Brief No 114, 2015).

It may be assumed that factors driving clan-based conflict produce a fertile ground for violent extremism, but clan conflict and violent extremism are rather simply correlated rather than causally related (Ngala 2016). Ngala (2016) further notes that the factors that drive clan conflicts in Wajir is divided leadership and those who favour operation of violent extremist hence driving clan-based conflicts unlike Mandera and Garissa which are exposed to greater risk factors, enabled mostly by cross-border clan ties, such as cross-border trade, smuggling networks, and corrupt border security official. These factors that drive clan conflict also enable extremist activities.

\section{Research Method}

\subsection{Location of the study area}

The research study was carried out within Wajir County located in Northeast Kenya. Wajir County, borders Somalia to the east and with a short border with Ethiopia to the Northwest. The climate is very dry and harsh. The location was purposively selected since it has been affected by clan conflicts in the recent past. The main clans residing in Wajir County are Ogaden, Degodia and Ajuran. Two locations were selected for the research within the Wajir County namely Wajir North (Bute Helu/Buna) and Wajir East/Township where clan conflict has been persistent since 2014. This study adopted an exploratory research design which seek to obtain information on the current situation that the researcher had little knowledge about it. The study explored the drivers of the clan-based conflicts that have persisted for decades. The researcher gathered information from the Key Informants from the study sites so as to comprehend and get in-depth report on the causes of clan conflicts. The study involved qualitative approach of data collection. In-depth interview to Key Informants were conducted involving face to face interviews to obtain information under study as the respondents possessed the information being targeted.

\subsection{Target population and Sample size}

The target population was stratified as clan elders, security agents, religious leaders and civil society organizations. A total of 31 respondents were interviewed comprising of clan elders (Degodia, Ogaden and Ajuran), NGO/CBOS representatives, religious leaders' and security agents. They were subjected to unique in-depth interview to generate information which aided in understanding the drivers of clan conflicts in Wajir County, Kenya. The respondents were selected using purposive and snowball approach due to the sensitivity of the research under study. Snowballing was important since it gave the researcher lead to the persons who had wealthy of information under study.

\subsection{Data collection strategy}

Interview guides were administered to the various respondents by the research assistants. The interview guides were based on the main objectives of the study. Research assistants were trained on how to administer the interviews guides. This approach was adopted due to sensitivity of the research and to overcome the language barriers of the respondents mainly clan elders whom majority were school drop outs and elderly. The research assistants were trained on research ethics as well on the contents of the questionnaire by the Lead researchers together with the partners from RUSI. The trained research assistants were sent to the field in pairs due to security issues. An introduction letter was also sought from the Regional 
Commissioner as an authority to undertake the research. While in the field the research assistants were required to record interviews on the field note book and later to type and email the soft copy of the field book content to the lead research on daily basis. Close monitoring was done through daily briefing. After the data collection the field book in hard copy were delivered to the Lead researcher to ascertain the validity of the collected data. During the data collection period the research assistants in Eldas were unable to conduct interview because it was under conflicts. Scanty data from the actual study site was collected and enriched by data collected from the periphery of the study site. The reason of the conflict in Eldas was that a chief belonging to Ajurian clan was murdered by the Degodia. This escalated the situation into clan wars. This volatility extended during the period of data collection.

\subsection{Data Analysis Strategy}

Data preparation included data editing, coding and grouping according topical areas which were consistent with intent of the research questions. The information obtained from the study was thematically analyzed according to the research questions. To generate narratives or discourses, content analysis that involve identification of specific characteristics or themes of information were carried out. After data analysis the Lead researcher and research assistants discussed the data outcomes using narratives that include verbalize presentation to ascertain the veracity_the information.

\section{Discussion}

This section discusses the data collected from the interviews with the aim of coming up with the key findings. The analysis was based on the specific objectives of the research. The specific objectives of the study were to assess the drivers of inter-clan and intra-clan-based conflicts in Wajir county and explore mitigation strategies of inter-intra clans and violent extremists' infiltration in Wajir county.

\subsection{Drivers of interclan conflict in Wajir County}

During the clan-based conflict, the community of Wajir County is divided into clans. Once conflicts vent people are injured and even killed simply because they belonged to a given clan. Basing on this clans serve the purpose of identification; knowing who is related to who'. It is worth noting that during conflicts brotherhood is based on clans. Some of the key drivers of the clan-conflicts in Wajir County are:

\section{a. Election/Constituency Boundaries Issues}

The villages and settlements in Wajir County are organized according to clans (Maas, n.d). This is in itself not an issue, was it not that members of other clans are often discouraged or even forbidden to settle in areas designed to a given clan. According to Maas (n.d) the main reason for settling according to clans is for protection or security against violent attacks from other clans.

The current state of relationship among the clan and sub-clans in Wajir North and Eldas area is unstable in some areas due to conflicts along border lines (Basir, Lakoley of Eldas and Malkagufo, Buna, Laysayo, Nyata and Ajawa of Wajir North) and between the clans (Ajuran and Degodia). The state of relationship among the clan/sub-clans in Wajir East and Township is usually stable and peaceful but tension rise during elections. According to History of Wajir 
(n.d) when Kenya became independent political borders defining constituencies were laid down throughout the country. The current constituencies boundaries do not match the colonial borders demarcated by British. This cause confusion where borders lies, there is no clear line whether to follow the British colonial boundaries or the Kenya independent political boundaries. Currently Degodia occupy four (4) sub counties (Wajir West, Eldas, Tarbaj and Wajir East) while Ajuran has only one sub-county that is Wajir North and Ogaden in Wajir South. The Wajir West constituency traditionally belonged to Ajuran until they lost to Degodia in the election of 1979 and 1983.

Since every clan wants its own representative in the constituency, a clear token of clannism rises coupled with tension in the constituency every five years with the nearing of elections between Jibrael of Degodia clan and Gelbaris and Waqle of Ajuran clan. This has led to several clan conflicts, especially Wajir North where Ajuran and Degodia inhabit including the recent conflict in Eldas Constituency in March 2018. This was a result of border disputes of the newly created constituency that is Eldas and Wajir North "These Degodia want to take what is all ours, a new constituency have been created and they still want to take it, we shall not accept under all means" an elderly man commented. The political elite try to build the image to gain sympathy from the community to intensity of competition in the public space (Hadirat et al, 2020). As noted above, elections are viewed as high stakes, zero-sum contests by clans fearful that victory by rival clans would institutionalize the rival's holding on the resources and eventually alienate the losers.

During electioneering period ascendants of Degodia clan sought to increase its numbers by bringing in Degodia from outside the constituency to vote. In 1992 the Degodia brought outsiders from the constituency to vote in expense of the local inhabitants of the area who are Ajuran. The Ajuran loss was seen as a sign of the declining fortunes of the Ajuran noting that Degodia are regarded as foreigner or aliens to Wajir county in early 1980s. This triggers conflict between the two clans. In an effort to resolve the conflict in the past the MP seat over which the two clans fought, the Kenyan government created a new parliamentary constituency, Wajir-North, intended to give the Ajuran their "own" seat in parliament. This is not a problem for the Ogaden, who are sure to win the southern constituency, nor for the Degodia, who are sure to win the western constituencies. It is however a problem for the Ajuran, who have to compete with the Degodia for Wajir West constituency. This explains why there is no conflict in the Wajir South and conflict in the Wajir North. Therefore, political candidates try to ensure a majority of their clan are in this 'remainder' constituency during Election Day. This tactic, embraced with the influence of many Somali Kenyan politicians resulted in Wajir County getting six constituencies.

Wajir County has six sub counties namely: Wajir South (Ogaden), Wajir North (Ajuran), Eldas (Degodia), Trabaj (Degodia), Wajir East pure (Degodia) and Wajir West split between Ajurans and $80 \%$ being Degodia. One chief noted that "The cause of the clan conflict between the clans is lack of knowledge on the actual border line, Ajuran say this while Degodia say that, this confusion causes conflict especially during elections" As pointed out by one respondent lack of proper knowledge in the border between the two warring clans has been the biggest issue on the ground each clan claiming the area under disputes belongs to them hence fueling clan conflicts.

Respondents admitted that political influence before or after election causes conflict since each clan want to dominate in power in order for them to retain the political influence and grab the scarce resources to the members of their own clans. One respondent pointed a case in Eldas Constituency where one MP from Degodia clan has remained in power for the 
last 20 years. He uses clan conflicts to remain in power. With elections coming up, politicians make clans even more important in their attempt to secure and retain seat in the National Parliament. The conflict thus shifted into an immaterial level, to the level of identity in political power or influence within the County.

Clan conflict between the Degodia and Ajuran clans was triggered by the competition over Member of Parliament (MP) constituencies. They feared that people, Degodia or Ajuran, of the Western constituency would come to their constituency to cast votes in favour of the opponent. Therefore, politicians stressed the importance of restricting the colonial borders though these borders are not parallel with the boundaries of the constituencies, the closing of the colonial borders prevents a lot of people from travelling. Once the politicians succeeded in closing the border points, they justify in the name of protecting scarce resources for their own clan. For instance, Eldas sub-county and Wajir North sub-county, the border lines are not clear and created a lot of confusions to the entire Wajir County hence source of conflict. The role of politician in the conflict is to retain their political seats and overpower other communities through financing, planning and organizing the attacks on the other clans. As noted by one clan elder "This is our constituency we can't allow the Masaare to rule us we must remove them from power under all circumstances, this is our land we can't allow others to lead us" A case in point is the conflict between the Masaare and Fai sub clan of Degodia after the 2017 general election in Wajir East constituency. The Fai were in power before the elections, after election Masaare took over the power and this created tension and fighting erupted.

\section{b. Devolved System Government}

Since the inception of the devolved system of government in Kenya, issue to do with sharing of County resources was inclined to those holding County leadership. Under the devolved government in 2013 the communities had high expectations out of poverty, inequality and high unemployment which were threat to the locals during the national government. According to Maas (n.d), Northern Kenya concept of clannism is more pronounced since the County positions are closely related to clans where community members identify themselves in order to achieve their agenda. Wajir County political influence is another cause since each clan want to dominate in county leadership and share the resource at disposal. Wajir County has few valuable resources that generated discrimination during allocation and distribution (Ibrahim \& Jenner, 1997; Menkhaus, 2015). During allocation of county resources, the county leaderships are more politically inclined rather than client based, hence absence of ties between Wajir elites and the political centre (Ibrahim \& Jenner, 1997); Menkhaus, 2008). Like other parts of the Northeast Kenya, Wajir County has a long history of neglect and repression by the National government (Emma, 2016).

While devolution holds many possibilities for a more inclusive approach and conflict settlement, it also holds a potential for further conflict as it has increased discrimination on resource sharing. Consequently, the large new county budget of about eight billion per year (FY 2016/17) have increased the stakes surrounding elections. The political elite based in the County mobilized clans to vote in blocs to maximize the control over county government revenues and other associated resources and gains, this brings animosity between the clans. It is clear that County gains under the devolved system of government are shared along clan lines. These gains include allocation of funds for infrastructure development such as boreholes, schools, hospitals, school bursaries, county revenues and employment. Unequal and biasness in distribution of County resources after elections generate politically driven clan 
violence for instance employment of the youth is inclined to the clan in position. The postelection phase of the devolved county government sparked clan conflict between clans in power and those not in power. This is supported by the Indonesian context that noted, "it is still too premature to say that the formation of new state institutions, which are mostly independent state institutions, have failed or succeeded" (Dema et al, 2020). It is more correct to say that the related formation shows "limited success," in the devolved system of governance.

\section{Competition Over Resources}

Community identification with clan accelerates conflict. In Wajir County, the conflict is drawn to the level of identity, i.e. the clan identity. If the cause of the conflict was dispute over grazing land and water, it could have simply remained limited to a conflict between shepherds. Instead, it turns into a conflict between entire clans, involving many individuals, whether shepherds or not. The conflict was drawn from a material level, the dispute over access to natural resources, to an immaterial level, the conflict between clans. The importance of the clan identity is stressed in such a way that the society became polarized between "Us", who belong to a certain clan, and "Them", who do not belong to that clan.

Access to natural resources is a primary driver of inter-clan conflicts with each clan identifying with community land. The community pastoral land of Wajir County is divided among communities, with clans committed to protecting their rights to land. Competition over access of the scarce resources such as water and pasture has been a common phenomenon among pastoralist communities since time immemorial. According to Menkhaus (2008), land pressure in Wajir county was worsened in the 1980s when the Degodia were pushed out of Isiolo County and into Wajir County by the Boranas. Anxiety over land access is a major underlying factor to clan conflicts. Competition over scarce resources and shrinking economic opportunities for the people also cause violence in the County due to land fragmentation and population increase. Given the fact that animal rearing is the main source of income, competition over and access to natural resources such as pasture and water have contributed to violence among clans living in the County. For instance, the conflicts between Degodia and Ajurans clans were due to boundary issues in Malkagufu village in 2007 and 2013 located in Wajir North constituency as a result of water and pasture for their animals. This can be explained by the fact that land is owned by clans and trespassing ones' clans can result to conflict especially during the dry spell. One chief noted that "Climate related factors coupled with large numbers of our animals are putting pressure on pasture and water, hence increasing competition over the resources among the clans during dry spell. This in itself creates tensions hence conflicts arise over the resources".

Omosa (2005) and Menkhaus (2008) noted that intra-ethnic/clan conflicts are related to natural resources in Wajir County. On his part, Omosa gave useful insights into how essential needs such as water and pasture are scarce during dry spell. This led to Degodia and Ajuran inter-clan conflicts. The growing human population and livestock herds and inappropriate placement of boreholes, have resulted in severe overgrazing in some areas and exacerbated by environmental degradation (Menkhaus, 2008). Since the majority of the people are pastoralists, environmental degradation and the reduction of pasture and water for their cattle creates fierce competition over scarce resources and leads to deadly conflicts. 


\subsection{Measures that are Existing to Mitigate Clan Conflicts}

This section highlights the existing measures in Wajir County to mitigate clan-based conflicts. In Wajir County some measures are in place to mitigate the clan-based conflict This has made actors to put measures to mitigate and address conflicts when they arise such as those occurred in June, 2014, June /July 2015, November 2016 and Feb 2018.

The existing measures include:

In order to mitigate conflicts among warring clans' in Wajir County the National government has deployed more security personnel from Administration Police (APs) and Kenya Police Reserve (KPR)) in the regions where conflict is persistence such as Wajir North and Eldas. The community feels that the security personnel take sides and therefore they don't assist in restoring peace as expected.

According to the clan elders, Civil Education has been enhanced with the aim of preaching peace and unity among the warring clans. The elders admitted that public and community gatherings have been reinstated with aim of preaching peace and unity on monthly basis in the market area and also shopping centre. The public gathering is assisting in restoring peace as indicated by the respondents. The County commissioner reported that the Government of Kenya has also trained elders in peace committees who sensitize the clan on the co-existence. These peace committees are working though they are facing financial challenges.

The County Commissioner and security agents reported that the national government is implementing community policy (Nyumba Kumi initiative). It is being advocated since it motivates the locals to pin point security threats before and the aftermath. Nyumba Kumi initiative is a government policy that requires that every residence must know his her neigbours and the activities they engage in a within distance ten households. The clan elders admitted that Nyumba Kumi initiative is assisting to achieve peace since the community is able to recognize any unusual incidence or occurrences and report it to security agents.

Some local NGOs/CBOs trains and creates awareness among the locals as reported by the respondents on the importance of keeping peace. Nevertheless, these measures have fairly worked in resolving the conflicts through reconciliation and negotiations though some challenges do persist as reported by the clan elders. The NGOs and CBO personnel interviewed reported that the main challenge they face in implementing peace initiatives is lack of enough funds and man power to spearhead the whole process of reconciliation and peace building.

Religious leaders reported that they are involved in restoring peace and unity among the conflicting communities. They resolve clan conflicts through mediating and having round table discussion between the warring clans which lead to paying of blood price of those killed. Chiefs organize public Baraza on behalf of Imams to sensitize the public. Baraza is a public gathering where the community members are invited and the chief's moderates while Imams address them. They preach peace and create awareness on the importance of keeping harmony among the clans. Religious groups affirmed that they are facing some challenges when organizing peace rallies, some of the challenges include depending on the politicians for funding who are the source of the conflicts, lack of political support from the leaders, lack of funds for hiring vehicles and poor transport network to the affected areas.

County Commissioner reported that military operations have been undertaken to disarm the locals with weapons in the areas of Wajir North and Eldas, specifically Basir and Lakoley of Eldas ward and Malkagufo, Buna, Leysao and Nyata of Wajir North constituency. The communities were requested to surrender any fire arms they possess voluntarily and those who 
didn't heed they were forced to surrender. The community never took this exercise positively since they complained use of excessive force and biasness during the operation. This was aimed to reduce the illegal weapons with the locals.

These measures have fairly been successful in resolving clan conflicts but some of the persisting challenges include chiefs don't have the will to do Nyumba kumi initiatives since they fear being victimized by the opposing clans. A case in point was in February 2018, when a chief belonging to Ajurian clan was murdered by the Degodia in Eldas. The CBOs have less resources (finances) to cater for everybody, during conflict and capacity to supply water and food to the poor.

\section{Conclusion}

According to Ngala (2016), five major clan conflicts has been documented, they include June 20, 2014, June 21, 2014, June /July 2015, November 2016 and February 2018. This implies that clan conflict is an eminent issue in Wajir County which is dynamic due to a number of factors. Owing to the nature of the region harsh climate, high poverty level due to unemployment and high illiteracy level the community is vulnerable to conflicts. Clan identity accelerates the conflict since each clan want to associate with his or her clan for security purposes. The study found that some of the key drivers of clan conflict in Wajir County include external forces, political influence, constituency boundaries, unequal sharing of county resources and competition over water and pasture. External forces such as clan brotherhood outside the county play a role in conflict in terms of supporting their brothers through weapons and finances. Proximity of Somali border is another force due to its volatility and weapons getting entry to the County while the unemployed youth who are purported to have joined Al Shaabab can easily return home to support and provide weapons during conflicts. Political influences ensue when political figure want to dominate in power.

This influence makes voting to be along clan lines in the name of acquiring resources for their clan. Constituency boundaries also fuels conflicts since each clan want to extend their boundary in order to get more seats during the elections like for the case of Ajuran. With devolution system of government, the marginalized communities thought it was a way of sharing resources but the resources were inclined to the clan that hold the County positions. This results in conflict after elections since they are being sidelined in resource sharing. Lastly scarcity of resources coupled with impacts of climate change led to competition of water and pasture hence conflict. Scholars have documented five clan conflict in Wajir county since 2014 as compared to the past since the Wajir Peace and Development Committee (WPDC) has lacked funding, recruitment is biased, the founder members have died and the county funds has made some of the elders take side. The WPDC maintained sustainable peace within the County and thus stimulated the reconciliation process hence reducing incidence of clan conflicts.

\section{References}

Demas B., Sudarsono, Rachmad S., and Muchamad A., (2020), Welfare Detection and Legal Effectiveness: Country Institutions Which the Authority is Regulated in Law in the Disputes of Authority, Budapest International Research and Critics Institute-Journal (BIRCI-Journal) Volume 3 (1): pp 227-238 
Emma E, (2016), The political conditions for local peacemaking: A comparative study of communal conflict resolution in Kenya Department of Peace and Conflict Research, Uppsala University Paper presented at the annual conflict of the Conflict Research Society, 7-9 September 2016, Trinity College Dublin.

Hadirat M., (2020), Political Reposition of Authority in South Nias DPRD Members in 2014 Election (A Study on Social Construction of Peter L. Berger), Budapest International Research and Critics Institute-Journal (BIRCI-Journal) Volume 3 (1):pp 262-269

History of Wajir (n.d.). In Political records Wajir, Vol I, DC/WAJ/3/1

Ibrahim, D. and Jenner, J. (1997), Wajir Community Based Conflict Management In USAID conference on conflict resolution in the great Horn of Africa.

International Crisis Group (2015), Kenya's Somali North East: Devolution and Security Crisis $\begin{array}{llll}\text { Group Africa } & \text { Briefing } & \text { No.114 Nairobi/Brussels }\end{array}$ https://www.crisisgroup.org/africa/horn-africa/kenya/kenya-s-somali-north-eastdevolution-and-security

Joint report by Garissa County Steering Group and Kenya Food Security Steering Group (KFSSG).

February (2016), In: Garissa County Annual Development Plan Report for the year 2015.

Lewis, M. (1961), A Pastoral Democracy: A Study of Pastoralism and Politics among the Northern Somali of the Horn of Africa. Published for International African Institute, London, New York and Toronto, Oxford University Press.

Maas V., (Unpublished) Verde in Wajir http://www.wajir.org/rapporten/Antoinette\%20Maas\%20$\% 20$ Vrede\%20in\%20Wajir.pdf (accessed on $25^{\text {th }}$ July 2018)

Menkhaus K., (2008), The rise of a mediated state in Northern Kenya: The Wajir story and its implications for state-building, Afrika focus Volume 21(2): pp. 23-38

Miyandazi L, (2012), Kenya's military intervention in Somalia. An intricate process http://www.accord.org.za/publication/kenya-s-military-intervention-insomalia/(accessed on 5th February 2018)

Narges, R., Fatemeh, S., and Shiva, Z., (2020), A Foucauldian Reading: Power in Awakening by Kate Chopin, Budapest International Research and Critics Institute-Journal (BIRCIJournal) Volume 3(1): pp 159-166

Ngala C., (2016) Violent Extremism and Clan Dynamics in Kenya, peace work number 123, United states of peace, Washington DC Web: www.usip.org

Omosa, E., (2005). The Impact of Water Conflicts on Pastoral Livelihoods: The Case of Wajir District in Northern Kenya. Winnipeg, Manitoba, International Institute for Sustainable

Policy Briefing Africa Briefing No.85 Nairobi/Brussels, 25 January 2012 International Crisis Group. Kenyan Somali Islamist Radicalization. 